\title{
MILITARY PHYSICAL TRAINING, MUSCULAR STRENGTH, AND BODY COMPOSITION OF BRAZILIAN MILITARY PERSONNEL
}

\author{
TREINAMENTO FISICO MILITAR, FORÇA MUSCULARECOMPOSIÇÃO CORPORALDE \\ MILITARES BRASILEIROS
}

ENTRENAMIENTO FÍSICO MILITAR, FUERZA MUSCULARY COMPOSICIÓN CORPORALDE MILITARES BRASILENOS

\author{
Samir Ezequiel da Rosa' \\ (Physical Education Professional) \\ Eduardo Camillo Martinez \\ (Physical Education Professional) \\ Runer Augusto Marson' \\ (Physical Education Professional) \\ Marcos de Sá Rego Fortes' \\ (Physical Education Professional) \\ José Fernandes Filho ${ }^{2}$ \\ (Physical Education Professional)
}

1. Instituto de Pesquisa da Capacitação Física do Exército (IPCFEx), Rio de Janeiro, RJ, Brazil. 2. Universidade Federal do Rio de Janeiro (UFRJ), Rio de Janeiro, RJ, Brazil.

\section{Correspondence:}

Rua Antonio Parreiras, 126/701, Ipanema, Rio de Janeiro, RJ Brazil. 22411-020.

samirdarosa@hotmail.com

\begin{abstract}
Introduction: Since 1965, the Brazilian Army (BA) has participated in peacekeeping missions of the United Nations (UN), sending large contingents to various parts of the world, such as Angola, Mozambique, East Timor and Haiti. To do so, the military must be in a minimum physical condition to face any obstacles in the course of action in the theater of operations. Objective: To verify the effects of Military Physical Training (MPT) on muscular strength of upper limbs, anthropometric variables and body composition of Brazilian military personnel of the 24th UN peacekeeping mission in Haiti. Methods: The sample consisted of 192 male soldiers with mean age of $23.2 \pm 36$ years. They observed a weekday residential regime, with a defined schedule of meals and activities and time off on weekends. The MPT was applied four times a week, 90 minutes long for 14 weeks and involved aerobic and resisted exercises. In the pre- and post-MPT period, body mass (MC), height, waist circumference (WC) and abdomen circumference (AC) were measured to calculate body mass index (BMI) and fat percentage (\%F) through the protocol of Salem.. In addition, 12-minute run tests, push-ups, pull up and abdominal flexions were performed to calculate the Rogers Index (RI). Results: When comparing pre- and post-MPT, a significant difference was observed in all anthropometric variables and body composition (BM, BMI and \%F) and in the Rl for the upper limb muscle strength. Conclusion: The 14-week MPT indicates an improvement in the anthropometric and body composition variables, as well as an increase in upper limb muscular strength in Brazilian soldiers of the UN peacekeeping contingents in Haiti. This study concluded that RI could be an effective tool for assessing military muscular strength. Level of Evidencell; Therapeutic studies - Investigating the results of treatment.
\end{abstract}

Keyword: Training; Military personnel; Muscle strength; Body composition.

\section{RESUMO}

Introdução: Desde 1965, o Exército Brasileiro (EB) participa das missões de paz da Organização das Nações Unidas (ONU) enviando grandes contingentes para diversos lugares do mundo, como Angola, Moçambique, Timor Leste e Haiti. Para isso, os militares precisam estar em condições físicas mínimas para enfrentar quaisquer obstáculos no decorrer das ações no teatro de operações. Objetivo: Verificar os efeitos do Treinamento Físico Militar (TFM) sobre a força muscular dos membros superiores, as variáveis antropométricas e a composição corporal de militares brasileiros integrantes do $24^{\circ}$ contingente de missão de paz da ONU no Haiti. Métodos: A amostra foi constituída de 192 militares do sexo masculino com média de idade de 23,2 $\pm 3,6$ anos. Eles cumpriram regime de internato, tendo atividades e refeições com horários definidos, sendo liberados nos finais de semana. OTFM foi aplicado quatro vezes por semana, com 90 minutos de duração por 14 semanas e envolveu exercícios aeróbicos e resistidos. No período pré e pós-TFM foram medidas massa corporal (MC), altura, circunferência da cintura (CC) e do abdome (CA) para calcular o índice de massa corporal (IMC) e o percentual de gordura $(\% \mathrm{G})$ com o protocolo de Salem. Além disso, foram realizados testes de corrida de 12 minutos, flexão de braço, abdominal supra eflexão na barra para calcular o índice de Rogers (IR). Resultados: Ao comparar os resultados pré e pós-TFM verificou-se diferença significativa em todas variáveis antropométricas e composição corporal (MC, IMC e\%G) e também no IR para força muscular dos membros superiores. Conclusão: O TFM em 14 semanas aponta melhora nas variáveis antropométricas e de composição corporal, bem como aumento da força muscular dos membros superiores em militares brasileiros integrantes dos contingentes de missões de paz da ONU no Haiti. Este estudo concluiu que o IR pode ser uma ferramenta eficaz para avaliação de força muscular de militares. Nível de Evidência Il; Estudos terapêuticos - Investigação dos resultados do tratamento.

Descritores: Treinamento; Militares; Força muscular; Composição corporal.

\section{RESUMEN}

Introducción: Desde 1965, el Ejército Brasileño (EB) participa en las misiones de paz de la Organización de las Naciones Unidas (ONU) enviando grandes contingentes a diversos lugares del mundo, como Angola, Mozambique, Timor Oriental y Haití. Para ello, los militares necesitan estar en condiciones físicas para hacer frente a cualquier obstáculo en el curso de las acciones en el teatro de operaciones. Objetivo: Observar los efectos del Entrenamiento Físico 
Militar (EFM) sobre la fuerza muscular de las extremidades superiores, las variables antropométricas y la composición corporal de los miembros brasileños del $24^{\circ}$ Contingente de Misión de Paz de la ONU en Haití. Métodos: La muestra fue constituida por 192 militares del sexo masculino con promedio de edad de 23,2 $\pm 3,6$ años. Ellos cumplieron régimen de internado con actividades y comidas en horarios definidos, siendo liberados los fines de semana. El EFM se aplicó cuatro veces por semana, con 90 minutos de duración durante 14 semanas e involucró ejercicios aeróbicos y resistidos. En los periodos pre y post-EFM fueron medidas masa corporal (MC), altura, circunferencia de la cintura (CC), del abdomen (CA), para calcular el índice de masa corporal (IMC) y el porcentaje de grasa corporal (\%G) con el protocolo de Salem. Además, se realizaron pruebas de carrera de 12 minutos, flexión de brazo, abdominal supra y flexión en la barra para calcular el Indice de Rogers (IR). Resultados: Al comparar los resultados prey post-EFM se observó diferencia significativa en todas las variables antropométricas y de composición corporal (MC, IMC, \%G) y también en el IR para fuerza muscular de las extremidades superiores. Conclusión: El EFM en 14 semanas muestra mejora en las variables antropométricas y de composición corporal, asi como aumenta la fuerza muscular de las extremidades superiores en militares brasileños integrantes de los contingentes de misiones de paz de la ONU en Haitti. Este estudio concluyó que el IR puede ser una herramienta eficaz para evaluar la fuerza muscular de los militares. Nivel de Evidencia II; Evidence Level II; Estudios terapéuticos - Investigación de los resultados del tratamiento.

Descriptores: Entrenamiento; Personal militar; Fuerza muscular; Composición corporal.

\section{INTRODUCTION}

Since 1965, the Brazilian Army (BA) has actively participated in peacekeeping missions managed by the United Nations (UN), sending large contingents to various locations worldwide such as Angola, Mozambique, East Timor and Haiti. In order to carry out these missions, the military need to be in a minimum physical condition to face any obstacles in the course of action in the theater of operations. ${ }^{1,2}$

In BA, the Terrestrial Operations Command (TOC), the center responsible for guiding and coordinating the preparation and employment of the military, designates the Army Physical Training Research Institute (IPCFEx) to evaluate and plan the physical preparation of contingents who work in the Theater of Operations outside the country.,4

Muscular strength is an important component of physical fitness, not only for sports activities but also for daily activities and maintaining physical fitness. ${ }^{5}$ In particular, the relative muscular strength of the upper limbs is fundamental for the development of several activities inherent to military training and operations. ${ }^{5}$

Furthermore, muscle strength can be defined as the maximum amount of force that a muscle or muscle group can generate in a specific pattern of movement performed at a given velocity ${ }^{6}$ or as the ability of the neuromuscular system to produce tension.?

The ability to support and lift the body weight with the upper limbs gives to the military a confidence they need in different situations, whether in actual combat activity or simulation, which reduces the likelihood of exposing their physical integrity to risks concerning military activities. ${ }^{5}$

The IPCFEx, physically, prepares all military personnel participating in UN peacekeeping missions, producing and implementing a physical training plan based on the military physical training (MFT) manual. ${ }^{4}$ This is necessary since, once integrated into the UN service, these military personnel perform various types of physical and operational activities that require, in addition to other physical valences, the relative muscular strength of their upper and lower limbs. ${ }^{3}$

Although the selection of the military is not limited to physical evaluation, TOC requires UN contingent members to be physically fit, health-conscious, and ready for combat. ${ }^{3}$

Currently there is no quick and objective parameter to assist in the physical selection of the Brazilian military personnel selected for UN peacekeeping missions, regarding the strength of upper limbs.
In this context, the study aimed to verify the effects of MFT on upper limb muscle strength, anthropometric variables and body composition of Brazilian military members of the 24th UN peacekeeping force in Haiti.

\section{MATERIALS AND METHODS}

\section{Sample}

The study was conducted at IPCFEX, located in the city of Rio de Janeiro, RJ, Brazil. A total of 192 military men, who were part of the 24th Brazilian Contingent of Peace Mission in Haiti, participated in the study. The sample had a mean age of $23.2 \pm 3.6$ years (mean \pm SD), mean height of $174.8 \pm 6.0 \mathrm{~cm}$ and body mass $75.0 \pm 8.8 \mathrm{~kg}$.

The inclusion criteria to participate in the study were two physical evaluations (12 minutes run, push up, pull up and abdominal supra $)^{8}$ and two anthropometric evaluations (body mass, height, circumference of the waist, abdomen and hip). Furthermore, individuals should be eligible for health examinations under the TOC guidelines. ${ }^{3}$

Those who were not eligible for health exams were excluded from the sample, and those who were, failed to carry out any physical exercise, and anthropometric assessments.

All participants, after receiving clarification on the procedures and risks to which they would be submitted, had the Free and Informed Consent Form signed by their legal representatives. The study was approved by the Ethics and Research Committee of the University Salgado de Oliveira-UNIVERSO, Niterói, RJ, Brazil and followed the established standards of the National Commission of Ethics and Research (NCER), CAAE: 55948016.1.0000.5289

This was a pre-experimental longitudinal study which was performed over a 14-week period. In the 1st and 14th weeks, physical and anthropometric assessments were performed to program the training plan and verify its effect. During the training period between the 2nd and 13th weeks the subjects were exposed to four weekly sessions of MPT, 90 minutes in total, always in the morning.

All volunteers remained in boarding school, from monday to friday, according to Brazilian Army and TOC regulations. During each week, the subjects were awakened around 6 o'clock in the morning, carried out personal hygiene and went to the cafeteria where they received a standardized breakfast (bread, eggs, cheese, juice, milk and fruit), without interference from the the amount of food consumed.

After breakfast, the subjects moved to the place of the MPT that began at 07:15 $\mathrm{min}$. At the end of the activity, the military received military 
instruction until lunchtime at 11:30 p.m. At the end of the meal, at 13:30, they resumed the new period of military instruction that ended before dinner time (6:00 pm). Sometimes the military instructions continued in the evening period starting after dinner, and closing never more than 10:00 pm. The subjects did not perform other type of physical activity during the study in question, due to being in boarding school. Thus, the impact of MPT can be assessed in a more accurate way.

The training plan was based on the principle of interdependence of volume and intensity progression, ${ }^{9}$ using the results obtained in the first physical evaluation. The MPT session followed the guidelines of the Brazilian Army's physical training manual ${ }^{9}$ combining warm-up, neuromuscular, cardiopulmonary and stretching exercises. Warm-up was always performed before the main exercise and stretching at the end of activities, always maintaining the guidelines of the MPT manual. ${ }^{9}$ Neuromuscular training used circuit training sessions and basic gymnastics, always establishing a gradual exercise load for muscular adaptation and future increase. ${ }^{9}$ The basic gymnastics load began in the first week with five repetitions of each exercise, and increased two repetitions every two weeks. Thus, in the 12th week, the subjects performed 11 repetitions. For the circuit training track, an initial load of two weeks with a passage on the track in 30 seconds of execution in each exercise was also applied. The load, as well as basic gymnastics, was also increasing every two weeks. However, the number of tickets and the execution time of each exercise were alternated. Thus, in the last two weeks the subjects performed three passes on the track, with one minute of execution in each exercise. ${ }^{9}$

Cardiopulmonary training used continuous running as a form of exercise. The load was applied gradually, using the guidelines of the Army MPT manual. ${ }^{9}$ A volume and intensity progression was established, based on the 12-minute race result of the first physical evaluation, ${ }^{8}$ differentiating from the results of 100 in 100 meters from 2000 to 3500 meters. A military who walked in 12 minutes 2700 meters, started his training in the first week with a load of 5600 meters in 30 minutes. The volume increase was gradual until the 9 th week (7300 meters in 43 minutes), increasing the intensity from the 10 th week (4500 meters in 21 minutes) and ending at the 12th week with 3900 meters in 18 minutes.

The two anthropometric evaluations were performed before any physical evaluation. The body mass (BM) was determined with the evaluated one being maintained in the orthostatic position, barefoot, using only swimsuit (bathing suit) with the aid of the digital scale of leader brand, model P150M, with a maximum load of $200 \mathrm{~kg}$ and an increase of $0.1 \% .^{10}$ The stature was measured with a metallic stadiometer, brand Sanny. The valves were standing erect, where the spleens extended and joined to the trunk, feet joined and maintaining the contact with the stadiometer by the heel, with the head adjusted to the Frankfurt plane. ${ }^{10}$ The measurements were performed with those evaluated in respiratory apnea, in order to minimize possible instabilities in the vertebral column. The body mass index (BMI) was calculated by the quotient between BM $(\mathrm{kg})$ and the square of height $(\mathrm{m})$. The waist (WC), abdomen (AC) and hip (HC) circumferences were measured with a 2M anthropometric gait, Sanny medical model, Starret, model: SN 4010. The WC measurement was performed as assessed in orthostatic position and the relaxed abdomen at the point of least circumference line of the last rib put with the tape in a horizontal plane. ${ }^{10}$ The AC was measured at the umbilical level with the relaxed abdomen. ${ }^{10}$ For the $\mathrm{HC}$ greater apparent circumference of the gluteus was used with the tape in the transverse plane. ${ }^{10}$ The measurements were made in triplicate and the median value was adopted. The waist-to-hip ratio (WHR) was verified by dividing waist circumference by hip circumference in centimeters.
To determine the body fat percentage (BFP), the Salem formula, developed for use in Brazilian military men, was used, according to a study done in 2008. ${ }^{11}$

The muscular shape of the upper limbs was evaluated by the Roger's Strenght Index (RI), ${ }^{12}$ using the results of the tests of arm flexion in the soil and arm flexion in the bar. ${ }^{9}$

\section{Statistical analysis}

To perform the descriptive analysis and inferential statistics of all data, the STATISTICA version 7.0 package was used. The shapiro-wilk test was applied to verify the normality of the sample. The t-test was used to describe the sample and to verify the correlation of the MPT, the Person's correlation test was used. The results were presented as mean \pm standard deviation and minimum and maximum, with significance level of $5 \%$ for paired data.

Table 1 presents the results of anthropometric variables and body composition, before the two physical evaluations.

Table 2 shows the results of the push and pull ups, together with the Roger index (IR), after the two physical evaluations. Both tables show mean values, standard deviation, maximum and minimum, and significance test.

The initial data show a significant difference in all means of results between the 1st and 2nd evaluations (Table 1 and 2).

Table 3 shows the correlation of the results of the motor variables (push up and pull up) with the anthropometric and body composition variables before and after the 12 weeks of physical training.

In the 1st evaluation, there were inversely significant $(p<0.05)$ correlations between push up, BFP and WC, and also significant correlations ( $p<0.05$ ) between 1st RI, BFP and WC. In the 2 nd evaluation, significant correlations $(p<0.05)$ were found between 2 nd $\mathrm{Rl}, \mathrm{BM}, \mathrm{BMI}$ and WC.

Table 1. Result of the test of difference of means between the anthropometric variables of the sample studied in the 1st and 2nd Evaluation.

\begin{tabular}{c|c|c|c|c|c|c|c|c|c}
\hline \multirow{2}{*}{ Variables } & \multicolumn{5}{|c|}{ 1a Evaluation $^{\text {a Evaluation }}$} & \multicolumn{5}{c}{ Test $\boldsymbol{t}$} \\
\cline { 2 - 11 } & Mean & S.D & Min & Max & Mean & S.D & Min & Max & p \\
\hline Age & 23,2 & 3,6 & 19 & 40 & 23,2 & 3,6 & 19 & 40 & $<0,05$ \\
\hline BM & 75,0 & 8,8 & 51,5 & 98,7 & 72,9 & 9,1 & 49,3 & 106,0 & $<0,05$ \\
\hline BFP & 13,9 & 4,0 & 4,5 & 25,0 & 11,9 & 3,7 & 4,3 & 26,3 & $<0,05$ \\
\hline IMC & 24,6 & 3,3 & 15,9 & 34,8 & 23,8 & 2,4 & 18,2 & 29,4 & $<0,05$ \\
\hline WC & 81,8 & 6,0 & 69,0 & 101,0 & 78,9 & 5,3 & 65,8 & 94,1 & $<0,05$ \\
\hline S.D. = Standard Deviation.
\end{tabular}

Table 2. Results of the test of difference of means between physical variables and Rogers Index of the sample studied in the 1st and 2nd Evaluation.

\begin{tabular}{c|c|c|c|c|c|c|c}
\hline & \multicolumn{3}{|c|}{$1^{\text {a }}$ Evaluation } & \multicolumn{3}{c|}{ 2a Evaluation $^{\text {a }}$} & Test $\boldsymbol{t}$ \\
\hline Variables & Push Up & Pull Up & RI & Push Up & Pull Up & RI & p \\
\hline Mean & 36,8 & 9,6 & 971,7 & 40,0 & 11,6 & 1740,4 & $<0,05$ \\
\hline S.D & 6,3 & 2,6 & 188,9 & 7,1 & 2,7 & 202,5 & $<0,05$ \\
\hline Min & 23,0 & 4,0 & 526,5 & 15,0 & 5,0 & 1319,7 & $<0,05$ \\
\hline Max & 53,0 & 20,0 & 1636,7 & 76,0 & 20,0 & 2405,5 & $<0,05$ \\
\hline
\end{tabular}

S.D. $=$ Standard Deviation; $\mathrm{Rl}=($ push up + pull up $) \times(B M+$ Height -60$) / 10$.

Table 3. Results of the Pearson correlation test between the motor and anthropometric variables of the sample studied in the 1 st and 2 nd evaluations.

\begin{tabular}{|c|c|c|c|c|c|c|}
\hline & \multicolumn{3}{|c|}{ 1a Evaluation } & \multicolumn{3}{|c|}{ 2a Evaluation } \\
\hline & $\begin{array}{c}\text { 1aPull } \\
\text { Up }\end{array}$ & $\begin{array}{c}\text { 1a Push } \\
\text { Up }\end{array}$ & $1^{\circ} \mathrm{RI}$ & $\begin{array}{c}\text { 1aPull } \\
\text { Up }\end{array}$ & $\begin{array}{c}\text { 1a Push } \\
\text { Up }\end{array}$ & $1^{\circ} \mathrm{RI}$ \\
\hline $\mathrm{BM}$ & $-0,03$ & $-0,12$ & $0,30^{*}$ & 0,03 & 0,09 & $0,43^{*}$ \\
\hline BFP & $-0,00$ & $-0,15^{*}$ & $0,19^{*}$ & $-0,01$ & $-0,01$ & 0,12 \\
\hline IMC & $-0,08$ & $-0,12$ & 0,09 & 0,01 & 0,03 & $0,23^{*}$ \\
\hline WC & $-0,05$ & $-0,18^{*}$ & $0,23^{*}$ & $-0,00$ & 0,02 & $0,27^{*}$ \\
\hline
\end{tabular}




\section{DISCUSION}

The objective of the present study was to verify the effects of military physical training on upper limb muscle strength, anthropometric variables and body composition of military members of the UN peacekeeping contingents in Haiti.

In this study it was verified that after the MPT there was a significant reduction of the anthropometric and body composition variables (BM, $\mathrm{BFP}, \mathrm{BMI}$ and WC), evidenced by the statistically significant difference $(p<0.05)$ found between the mean values.

A study conducted by Neves et al.,13 in the city of Curitiba, evaluated a sample of 195 military personnel from the EB, mean age of 23.1 ( \pm 7.6) years, and found a mean fat percentage of $14.6 \pm 6.4$ )\%, values close to those found in the present study. In another study in a sample of 92 soldiers, with a mean age of $20( \pm 1.8)$ years, performed by Botelho et al. ${ }^{14}$ the percentage of fat obtained was $13.8( \pm 5.1) \%$.

Polito ${ }^{15}$ also verified that there was a significant reduction in the BFP and reduction in the WC, after subjects underwent 12 weeks of weight training, 3 times a week, composed of 10 exercises of 2 sets of 10-20 repetitions.

There are few studies involving MPT and changes in anthropometric variables and body composition, which makes it difficult to discuss.

Irving et al. ${ }^{16}$ demonstrated that WC reduction was more significant with high intensity exercises when compared to low intensity exercises. In the study by Thomas, ${ }^{17}$ it was observed that WC and AC reduced with weight loss, but soon afterwards increased significantly with weight gain. In a recent study by Lemes et al. ${ }^{18}$ after 21 weeks of MPT, military personnel from the military police of São Paulo reduced BM and BFP, corroborating the results of the research presented here.

Rudzki ${ }^{19}$ analyzed the 12-week effect of MPT on the Australian military and found no significant difference in mean BMI. This was not the case with the military of the 24th Peace Mission Contingent.

Also in this study, the MPT for 14 weeks promoted an increase in upper limb muscle strength, as demonstrated by the statistically significant difference found between the mean values of Rl, pre and post MPT.

There were no studies on IR and MFT in the age range of the study in question (23 years). In truth there are practically not many works on
$\mathrm{Rl}$ itself. The findings found mostly involve push up and pull up with military mean age \pm 18 years. ${ }^{18,20}$

Avila et al..$^{20}$ in a study carried out at the Preparatory School of Army Cadets (PSAC), in the city of Campinas, SP, in 287 students with a mean age of 18.33 ( \pm 1.26 ) years, after 13 weeks of MPT found an average of (8.5 \pm 3$)$ push up and $(29.9 \pm 7.8)$ pull up.

Another article published by Silva et al., ${ }^{21} 72$ military men aged between 18 and 19 years were submitted to the pull up with a result of $8.0( \pm 4)$ repetitions. These results were close to those obtained in the present study, with initial values for the $9.6 \pm 2.6$ pull up test and push up (36.8 \pm 6.3 ). However, these data are considered to be above average when compared to the normative values of Pollock and Wilmore (1993). ${ }^{22}$

Lemes $^{18}$ suggested that after 21 weeks of MPT there was a significant improvement in push up and pull up rates, increasing localized muscular resistance.

In the present sample, the relative strength tests calculated by RI showed a significant correlation $(p<0.05)$ with the anthropometric variables of BM, BFP and WC before the MPT. However after 14 weeks of MPT the correlation remained moderately significant for BM and WC alone. It was also verified that the BMI also showed a significant correlation with the RI after the MPT.

In the application of Pearsonss linear correlation tests between the anthropometric and body composition variables (BM, BFP, WC and BMI) and the results of the tests applied in the two evaluations separately (push up and pull up), there was a correlation inversely significant only between the mean of pull up and BFP and the WC of the 1st evaluation.

\section{CONCLUSION}

Military physical training in a systematized manner for 14 weeks points to an improvement in the anthropometric and body composition variables, as well as to increase the muscular strength of upper limbs in Brazilian military members of the UN peacekeeping contingents in Haiti. Further, this study concluded that RI may be an effective tool for assessing relative muscle strength of the military concerned.

All authors declare no potential conflict of interest related to this article.

AUTHORS' CONTRIBUTIONS: Each author made significant individual contributions to this manuscript. SER (0000-0003-3355-0626)*: was responsible for the drafting of the entire research project, data collection, data analysis, writing of the article, statistical analysis and revision. MSRF (000-0003-2038-5545)*, ECM (0000-0003-3728-9859)*, RAM (000-0002-5248-7717)* and JFF (000-002-9044-0899)* : were responsible for the data analysis, writing of the article and revision. *ORCID (Open Researcher and Contributor ID).

\section{REFERENCES}

1. Rosa SE, Neves EB. Prevalência de desordens psicológicas e processo de seleção dos militares brasileiros para as forças de manutenção da paz no Timor Leste. Giro do Horizonte. 2009;2(1):20-9.

2. Lester ME, Knapik JJ, Catrambone D, Antczak A, Sharp MA, Burrell L, et al. Effect of a 13-month deployment to Iraq on physical fitness and body composition. Mil Med. 2010;175(6):417-23.

3. COTER, Exército Brasileiro. Diretriz de preparação específica de tropa para missão de paz (BRABATT 2). 2011.

4. Rosa SE, Fernandes Filho J, Fortes MS, Chain AC, Martinez EC. Serum biochemical markers and anthropometric measurements in the brazilian army militaries selected for the United Nations Peacekeeping Mission in Haiti. Global Journal for Research Analysis. 2015;4(7):38-40.

5. Silva EB, Teixeira MS, Gomes PS. Antropometria e força muscular relativa de membros superiores. Revista Brasileira de Fisiologia do Exercício, 2003;2(1):29-38.

6. Fleck SJ, Kraemer WJ. Fundamentos do treinamento de força muscular. 2.ed. Porto Alegre: Artmed; 1999

7. Badillo JJ, Ayestarán EG, Dornelles MS, Pinto RS. Fundamentos do treinamento de força: aplicação ao alto rendimento desportivo. 2. ed. Porto Alegre: Artmed; 2001. 284p.

8. Estado-Maior do Exército, EME. Diretriz para o treinamento físico militar do Exército e sua avaliação. EGGCF; 2008.

9. Estado-Maior do Exército, EME. Manual de Campanha C 20-20: treinamento físico militar. 3.ed. EFGG; 2002.

10. Fernandes Filho J. A prática da avaliação física: testes, medidas, avaliação física em escolares, atletas e academias de ginástica. 2. ed. rev. atual. Rio de Janeiro: Shape; 2003. 268 p.

11. Salem M. Desenvolvimento e validação de equações e índices para a determinação da gordura corporal relativa, em militares brasileiros, a partir de medidas antropométricas. [Rio de Janeiro,RJ]: Fundação Oswaldo Cruz; 2008

12. Bale P. The relationship of physique and body composition to strength in a group of physical education students. Brit J Sports Med. 1980;14(4):193-8.
13. Neves EB, Ripka WL, Ulbrichht L, Wan Stadnik AM. Comparação do percentual de gordura obtido por bioimpedância, ultrassom e dobras cutâneas em adultos jovens. Rev. Bras. Med. Esporte. 2013;19(5):323-7.

14. Botelho RB, Avena F, Veras M, Zandonadi RP. Nutritional adequacy of meals offered and consumed by soldiers of the brazilian army. Rev Nutr. 2014;27(2):229-39.

15. Polito MD, Cyrino ES, Gerage AM, Nascimento MA, Januário RS. Efeito de 12 semanas de treinamento com pesos sobre a força muscular, composição corporal e triglicérides em homens sedentários. Rev Bras Med Esporte. 2010;16(1):29-32.

16. rving BA, Davis CK, Brock DW, Weltman JY, Swift D, Barrett EJ, et al. Effect of exercise training intensity on abdominal visceral fat and body composition. Med Sci Sports Exerc. 2008;40(11):1863-72.

17. Thomas TR, Warner SO, Dellsperger KC, Hinton PS, Whaley-Connell AT, Rector RS, et al. Exercise and the metabolic syndrome with weight regain. J Appl Physiol. 2010;109(1):3-10.

18. Lemes B, Vieira SS, Silva Jr JA, Carvalho PT, Costa WO, Bocalini DS, et al. Treinamento físico militar modifica parâmetros antropométricos e funcionais. Conscientiae saúde. 2014;13(1):31-8.

19. Rudzki SJ. The effect of a modified physical training program in reducing injury and medical discharge rates in australian army recruits. Mil Med. 1999;164(9):648-52.

20. Avila JA, Lima Filho PD, Pascoa MA, Tessutti LS. Efeito de 13 semanas de treinamento físico milita sobre a composição corporal e o desempenho físico doa alunos da Escola Preparatória de Cadetes do Exército. Rev Bras Med Esporte. 2013;19(5):363-6.

21. Silva EB, Teixeira MS, Gomes PS. Antropometria e força muscular relativa de membros superiores. Rev Bras Fisiol Exerc. 2003;2(1):29-38.

22. Pollock ML, Wilmore JH. Exercícios na saúde e na doença: avaliação e prescrição para prevenção e reabilitação. 2. ed. Rio de Janeiro: Medsi, 1993. 